Article

\title{
Antischistosomal Properties of Hederacolchiside A1 Isolated from Pulsatilla chinensis
}

\author{
Naixin Kang ${ }^{1}$, Wenhua Shen ${ }^{2}$, Hongwei Gao ${ }^{3}$, Yulin Feng ${ }^{2}$, Weifeng Zhu ${ }^{2}$, Shilin Yang ${ }^{1,2}$, \\ Yanli Liu ${ }^{4, *}$, Qiongming $\mathrm{Xu}^{1, *}$ and $\mathrm{Di} \mathrm{Yu}^{5}$ (i) \\ 1 Department of Pharmacognosy, College of Pharmaceutical Science, Soochow University, Suzhou 215123, \\ China; carnation518@hotmail.com (N.K.); yangshilin@suda.edu.cn (S.Y.) \\ 2 College of Pharmaceutical Science, Jiangxi University of Traditional Chinese Medicine, Nanchang 330006, \\ China; shwh94@outlook.com (W.S.); fengyulin2003@126.com (Y.F.); zwf0322@126.com (W.Z.) \\ 3 College of Pharmacy, Guangxi University of Chinese Medicine, Nanning 530001, China; \\ gaohongwei06@126.com \\ 4 Department of Pharmacology, College of Pharmaceutical Science, Soochow University, Suzhou 215123, China \\ 5 Department of Immunology, Genetics and Pathology, Science for Life Laboratory, Uppsala University, \\ 75105 Uppsala, Sweden; di.yu@igp.uu.se \\ * Correspondence: liuyanli@suda.edu.cn (Y.L.); xuqiongming@suda.edu.cn (Q.X.); \\ Tel.: +86-0512-6956-1421 (Y.L. \& Q.X.); Fax: +86-0512-65882089 (Y.L. \& Q.X.)
}

Received: 3 May 2018; Accepted: 9 June 2018; Published: 13 June 2018

\begin{abstract}
Background: Schistosomiasis is a major neglected disease for which the current control strategy involves mass treatment with praziquantel, the only available drug. Hence, there is an urgent need to develop new antischistosomal compounds. Methods: The antischistosomal activity of hederacolchiside A1 (HSA) were determined by total or female worm burden reductions in mice harboring Schistosoma japonicum or S. mansoni. Pathology parameters were detected on HSA against 1-day-old S. japonicum-harboring mice. Moreover, we confirmed the antischistosomal effect of HSA on newly transformed schistosomula (NTS) of S. japonicum in vitro. Results: HSA, a natural product isolated from Pulsatilla chinensis (Bunge) Regel, was initially corroborated to possess promising antischistosomal properties. We demonstrated that HSA had high activity against S. japonicum and S. mansoni less in 11 days old parasites harbored in mice. The antischistosomal effect was even more than the currently used drugs, praziquantel, and artesunate. Furthermore, HSA could ameliorate the pathology parameters in mice harboring 1-day-old juvenile $S$. japonicum. We also confirmed that HSA-mediated antischistosomal activity is partly due to the morphological changes in the tegument system when NTS are exposed to HSA. Conclusions: HSA may have great potential to be an antischistosomal agent for further research.
\end{abstract}

Keywords: hederacolchiside A1; Schistosoma japonicum; Schistosoma mansoni; antischistosomal

\section{Introduction}

Schistosomiasis is a chronic and debilitating disease caused by digenetic trematodes from the genus Schistosoma mainly comprising three species: Schistosoma japonicum, S. mansoni and S. haematobium [1,2]. It is the second most frequent parasitic disease affecting humans after malaria, the global burden of schistosomiasis has been estimated to exceed 70 million disability-adjusted life years [3], but even the higher estimate might be an underestimation of the true burden $[2,4,5]$. According to the investigation of World Health Organization in 2012, around 800 million individuals are at risk of contracting the disease and 239 million people have been infected by schistosomes, whereas schistosomiasis has not evoked enough focus in this field [6,7]. Generally, human infections occur after penetration of the skin by the infectious larvae, or cercariae, and migration of the adult 
parasite to the portal vasculature surrounding the intestinal tract (S. mansoni and S. japonicum) or the vesicle plexus of the bladder (S. haematobium) [7]. Morbidity due to schistosomiasis includes hepatic and intestinal fibrosis (S. mansoni and S. japonicum), and ureteric and bladder fibrosis and calcification of the genitourinary tract (S. haematobium) [8].

As it stands now, the only clinical available drug against schistosomiasis is praziquantel, that has been used for 40 years [9]. Recently, a deluge of evidences indicated that the drug resistance of praziquantel has emerged in the clinic $[10,11]$. Praziquantel has little or no effect on eggs and immature worms [12], so pre-patent or newly acquired infections cannot be cured by praziquantel $[9,13]$. In order to provide new hit and lead compounds, the search for anthelmintic compounds from natural sources has intensified [14]. Natural products have been the source of medicines for thousands of years, and also provide modern medicine with effective pharmaceuticals for the treatment of diseases caused by parasites [15-17]. Artemisinin, isolated from the plant Artemisia annua, has been effectively used for schistosomiasis control [18], however, this drug is confined to the young developmental stages of the parasites.

Pulsatilla chinensis (Bunge) Regel, a traditional Chinese medicine with a long history, exhibits "blood-cooling" and detoxification activities. It has been widely used for adjunctive treatment of intestinal amebiasis, malaria, vaginal trichomoniasis, bacterial infections and malignant tumors [19-22]. Recent studies have found that various $P$. chinensis extracts and fractions had antiprotozoal activity against Giardia intestinalis [23] and selectively inhibited the growth of human intestinal bacteria, such as E. coli. and Clostridium perfringens [24]. Hederacolchiside A1 (HSA), a known structure which contains a trisaccharide scaffold, manifests strong and broad-spectrum antiproliferation inhibitory activities against human cancer cell lines [25]. However, up to now, there is little knowledge about the antischistosomal activity of HSA. In this study, we demonstrate that HSA have antischistosomal activity, affecting parasite viability both in vivo and in vitro.

\section{Results}

\subsection{HSA Has Antischistosomal Activity against Juvenile and Adult S. japonicum}

Our previous injection toxicity test study found that the mouse median lethal dose $\left(\mathrm{LD}_{50}\right)$ by intravenous injection of HSA is $21.05 \mathrm{mg} \cdot \mathrm{kg}^{-1}$. Moreover, mouse could be treated with $8 \mathrm{mg} \cdot \mathrm{kg}^{-1}$ HSA by intraperitoneal injection with no obvious toxicity. In view of the promising antischistosomal activity of HSA, total and female worm burden reductions in juvenile (14-day-old) (Figure 1B) and adult (35-day-old) (Figure 1C) S. japonicum harbored mice decreased in a time and dose-dependent manner. In the juvenile infection model, total and female worm burden reductions of $59.9 \%$ and $62.4 \%$ were achieved with $8 \mathrm{mg} \cdot \mathrm{kg}^{-1} \mathrm{HSA}$, respectively (Table 1). Moreover, intraperitoneal administration of $8 \mathrm{mg} \cdot \mathrm{kg}^{-1} \mathrm{HSA}$ on mice infected with adult $S$. japonicum resulted in total and female worm burden reductions of $53.2 \%$ and $65.8 \%$, respectively (Table 1 ). These results revealed the antischistosomal activity of HSA against both juvenile and adult S. japonicum with a dose-response relationship.

Table 1. Total and female worm burdens in the different dosage of HSA, praziquantel or artesunate treatment against the schistosomula and adult worms of $S$. japonicum.

\begin{tabular}{ccccc}
\hline \multirow{2}{*}{ Treatment (Dose $\mathbf{~ m g} \cdot \mathbf{k g}^{\mathbf{- 1}}$ ) } & \multicolumn{4}{c}{ Worm Reduction Rate (\%) } \\
\cline { 2 - 5 } & Total & Female & Total & Female \\
\hline & \multicolumn{2}{c}{$14-18$ days } & $35-39$ days \\
\hline Control & - & - & - & - \\
HSA (8) & 59.9 & 62.4 & 53.2 & 65.8 \\
HSA (6) & 47.6 & 52.6 & 32.4 & 52.6 \\
HSA (4) & 29.3 & 5.3 & 21.8 & 2.9 \\
praziquantel (300) & 52.0 & 45.6 & 85.2 & 83.2 \\
artesunate (300) & 85.1 & 85.0 & 92.4 & 94.7 \\
\hline
\end{tabular}


A

B

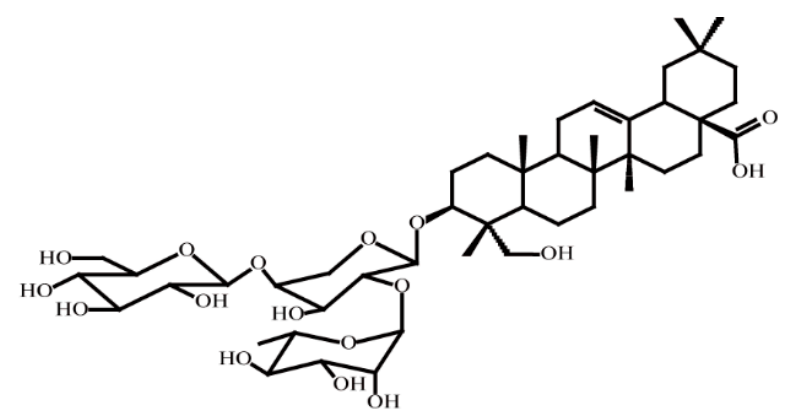

C
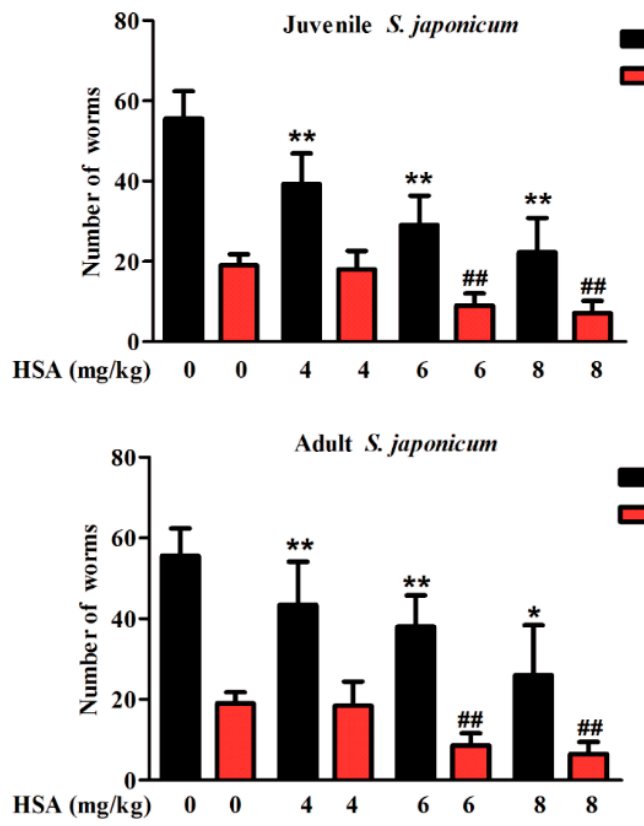

Figure 1. Dose-response relationship of HSA was administered to mice harboring S. japonicum. (A) Chemical structure of HAS; (B) 4-8 mg $\mathrm{kg}^{-1} \mathrm{HSA}$ was administered to mice harboring 14-day-old juvenile S. japonicum; (C) $4-8 \mathrm{mg} \cdot \mathrm{kg}^{-1} \mathrm{HSA}$ was administered to mice harboring 35 day-old adult S. japonicum. Mice were treated by intraperitoneal administration of $4-8 \mathrm{mg} \cdot \mathrm{kg}^{-1} \mathrm{HSA}$ as shown in Materials and Methods. Infected untreated (Negative control) mice were treated with vehicle. Each bar represents the mean $\pm \mathrm{SD}\left({ }^{*} p<0.05,{ }^{* *} p<0.01\right.$ vs. total worms of untreated group, $t$-test; ${ }^{\# \#} p<0.01$ vs. female worms of untreated group, $t$-test).

\subsection{HSA Was Superior in Inhibiting S. japonicum Less than 11 Days Old}

Since $8 \mathrm{mg} \cdot \mathrm{kg}^{-1}$ HSA showed the highest activities against juvenile and adult stages of S. japonicum, next, a single intraperitoneal dose of $8 \mathrm{mg} \cdot \mathrm{kg}^{-1} \mathrm{HSA}$ was used to investigate the stage-specific susceptibility of HSA against S. japonicum. Table 2 summarizes the antischistosomal activity of HSA shortly after infection (1-day post-infection) and until 49 days post-infection. Regardless of the timing of HSA administration when mice were infected with juvenile or adult S. japonicum, total and female worm numbers were reduced highly significant in HSA-treated mice (Table 2). HSA administration to mice harboring 1-, 7-day-old S. japonicum showed more effectiveness than other infected stages. More importantly, $8 \mathrm{mg} \cdot \mathrm{kg}^{-1} \mathrm{HSA}$ was highly active against 1 -day-old S. japonicum harbored in mice, and the antischistosomal activity of HSA was better than the positive drugs, praziquantel and artesunate (Figure 2). These results demonstrated that HSA showed significant antischistosomal activity on the different development stage of S. japonicum, especially for 1-day-old S. japonicum. 


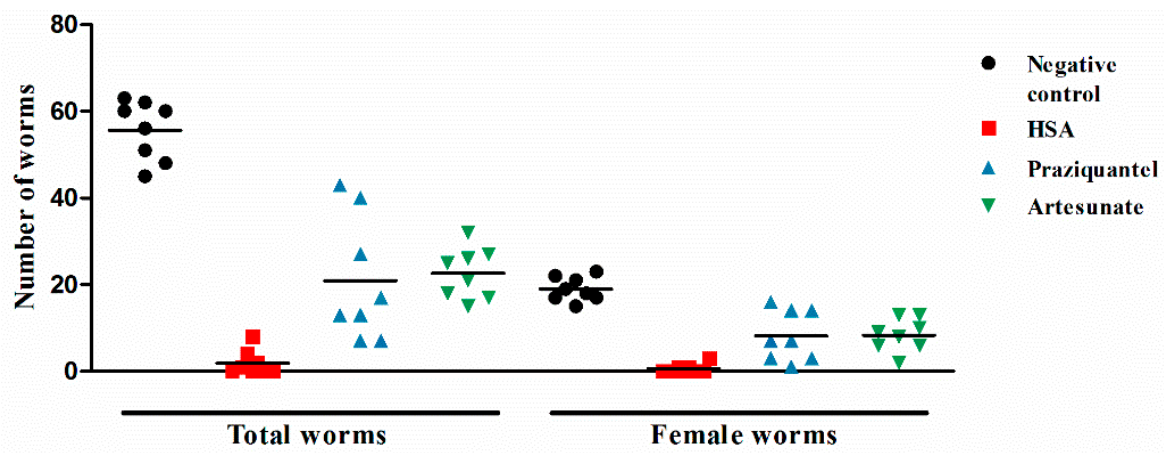

Figure 2. The antischistosomal effect of HSA against 1-day-old juvenile S. japonicum harbored in mice. Each point represents data from an individual treated or infected untreated mouse. Horizontal bars indicate mean values. The means $\pm \mathrm{SD}(\mathrm{n}=8)$ for each experimental condition are as follows: Total (untreated: $55.6 \pm 6.8$; HSA: $1.9 \pm 2.7$; praziquantel: $20.9 \pm 13.3$; artesunate: $22.6 \pm 5.5$ ) and female (untreated: $19.0 \pm 2.8$; HSA: $0.6 \pm 1.0$; praziquantel: $8.1 \pm 5.4$; artesunate: $8.4 \pm 3.5$ ).

Table 2. Stage-specificity of a single $8 \mathrm{mg} \cdot \mathrm{kg}^{-1}$ dose HSA, praziquantel or artesunate was administered to mice infected with $S$. japonicum.

\begin{tabular}{cccccc}
\hline $\begin{array}{c}\text { Treatment Stage of } \\
\text { Post-Infection }\end{array}$ & Treatment (Dose mg/kg) & \multicolumn{2}{c}{ Mean Number of Worms (SD) } & Worm Burden Reduction (\%) \\
\hline \multirow{2}{*}{ 1-5 days } & & Total & Female & Total & Female \\
& - & $55.6(6.8)$ & $19.0(2.8)$ & - & - \\
& HSA (8) & $1.9(2.7)^{* * *}$ & $0.6(1.0)^{* * *}$ & 97.2 & 94.7 \\
& praziquantel (300) & $20.9(13.3)^{* * *}$ & $8.1(5.4)^{* * *}$ & 62.4 & 57.2 \\
& artesunate (300) & $22.6(5.5)^{* * *}$ & $8.4(3.5)^{* * *}$ & 59.3 & 55.9 \\
\hline 7-11 days & HSA (8) & $5.5(3.3)^{* * *}$ & $1.6(3.3)^{* * *}$ & 90.0 & 89.5 \\
& praziquantel (300) & $22.4(6.8)^{* * *}$ & $7.6(2.9)^{* * *}$ & 55.6 & 59.9 \\
& artesunate (300) & $26.4(11.9)^{* * *}$ & $10.0(5.0)^{* *}$ & 52.5 & 47.4 \\
\hline 14-19 days & HSA (8) & $22.3(8.6)^{* * *}$ & $7.2(3.1)^{* * *}$ & 60.7 & 63.2 \\
& praziquantel (300) & $26.7(9.5)^{* * * *}$ & $10.3(3.2)^{* * *}$ & 52.0 & 45.6 \\
& artesunate (300) & $8.3(5.9)^{* * *}$ & $2.9(2.2)^{* * *}$ & 85.1 & 85.0 \\
\hline 21-25 days & HSA (8) & $24.6(9.6)^{* * * *}$ & $6.4(4.1)^{* * *}$ & 55.4 & 68.4 \\
& praziquantel (300) & $7.9(5.8)^{* * *}$ & $5.0(3.5)^{* * * *}$ & 85.9 & 73.7 \\
& artesunate (300) & $8.7(3.8)^{* * *}$ & $5.4(2.8)^{* * *}$ & 84.3 & 71.4 \\
\hline 28-32 days & HSA (8) & $32.6(7.1)^{* * * *}$ & $6.1(1.8)^{* * *}$ & 41.1 & 68.4 \\
& praziquantel (300) & $4.3(3.4)^{* * *}$ & $3.5(2.5)^{* * *}$ & 92.2 & 81.6 \\
& artesunate (300) & $1.5(1.9)^{* * *}$ & $1.3(1.6)^{* * *}$ & 97.3 & 93.0 \\
\hline $35-39$ days & HSA (8) & $26.0(12.4)^{* *}$ & $6.5(3.1)^{* * *}$ & 53.2 & 65.8 \\
& praziquantel (300) & $8.2(14.9)^{* *}$ & $3.2(5.9)^{* * *}$ & 85.2 & 83.2 \\
& artesunate (300) & $4.3(4.0)^{* * *}$ & $1(1.2)^{* * *}$ & 92.4 & 94.7 \\
\hline
\end{tabular}

${ }^{* *} p<0.01$ vs. the negative control group, $t$-test; ${ }^{* * *} p<0.001$ vs. the negative control group, $t$-test.

\subsection{The Efficacy Advantage of HSA against 1-Day-Old and 7-Day-Old Juvenile S. mansoni}

To determine the promising antischistosomal properties of HAS (and due to limited resources), we tested the anti-parasite effect of HSA on juvenile (1-, 7-, 21-day-old) and adult (42-, 49 day-old) S. mansoni harbored in mice. As Table 3 shows, HSA resulted in high and comparable total and female worm burden reductions when given to mice infected with either juvenile or adult stages of S. mansoni. At a single dose of $8 \mathrm{mg} \cdot \mathrm{kg}^{-1}$, HSA achieved worm burden reductions of 88.6 to $80.7 \%$ in mice harboring 1-day-old and 7-day-old juvenile S. mansoni, respectively. We still observed moderate total and female worm burden reductions of 68.3 to $84.1 \%$ in mice harboring 21-day-old juvenile and 49-day-old adult $S$. mansoni treated with a single dose of $8 \mathrm{mg} \cdot \mathrm{kg}^{-1} \mathrm{HSA}$ (Table 3). Comparing with the untreated group, the significant decrease in total and female worm number was shown in all 
HSA-treated groups. These results indicated that HSA also had promising antischistosomal properties against 1-day-old and 7-day-old juvenile S. mansoni, and that was even better than the positive drugs.

Table 3. Stage-specificity of a single $8 \mathrm{mg} \cdot \mathrm{kg}^{-1}$ dose HSA, praziquantel or artesunate was administered to mice infected with $S$. mansoni.

\begin{tabular}{|c|c|c|c|c|c|}
\hline \multirow[t]{2}{*}{$\begin{array}{c}\text { Treatment Stage of } \\
\text { Post-Infection }\end{array}$} & \multirow[t]{2}{*}{ Treatment (Dose mg/kg) } & \multicolumn{2}{|c|}{ Mean Number of Worms (SD) } & \multicolumn{2}{|c|}{ Worm Burden Reduction (\%) } \\
\hline & & Total & Females & Total & Females \\
\hline \multirow{2}{*}{$1-5$ days } & HSA $(8)$ & $4.4(2.7)^{* * *}$ & $1.0(1.5)^{* *}$ & 88.6 & 92.9 \\
\hline & praziquantel (300) & $5.3(5.4)^{* * *}$ & $2.3(2.6)^{* *}$ & 86.2 & 83.8 \\
\hline \multirow{2}{*}{ 7-11 days } & praziquantel (300) & $13.2(6.3)^{* *}$ & $2.5(1.5) * *$ & 65.6 & 82.3 \\
\hline & artesunate (300) & $23.8(11.2)$ & $6.5(3.6) *$ & 37.7 & 54.0 \\
\hline \multirow[t]{3}{*}{ 21-25 days } & HSA $(8)$ & $12.1(7.0)^{* *}$ & $4.3(3.3) *$ & 68.3 & 70.0 \\
\hline & praziquantel (300) & $16.7(10.3) *$ & $5.0(3.7) *$ & 56.4 & 64.6 \\
\hline & artesunate (300) & $1.5(1.3)^{* * *}$ & $0.2(0.4)^{* *}$ & 96.1 & 98.8 \\
\hline \multirow[t]{3}{*}{ 49-53 days } & HSA (8) & $11.3(4.1)^{* *}$ & $2.5(1.4)^{* *}$ & 70.6 & 82.3 \\
\hline & praziquantel (300) & $1.3(0.7)^{* *}$ & $0.3(0.5)^{* * *}$ & 96.5 & 97.6 \\
\hline & artesunate (300) & $13.7(7.0)^{* *}$ & $3.8(2.0)^{* *}$ & 64.3 & 72.9 \\
\hline
\end{tabular}

${ }^{*} p<0.05,{ }^{* *} p<0.01 * * * p<0.001$ vs. the Negative control group, $t$-test.

\subsection{HSA Inhibited Liver Damage in S. japonicum-Infected Mice}

Chronic morbidity during infection with S. japonicum develops as a result of schistosome eggs that lodge in the liver, gut and other organs, which causes extensive tissue damage [8]. To evaluate the potential effect of HSA on tissue egg loads, liver tissues of infected mice were digested separately in $5 \% \mathrm{KOH}$ and eggs/g tissues were calculated. The highest reduction percentages of ova in tissues were recorded in HSA-treated mice harboring 1-day-old juvenile S. japonicum (99.3\%) (Table 4).

Table 4. Ova load in S. japonicum infected mice received HSA, praziquantel or artesunate treatment.

\begin{tabular}{|c|c|c|}
\hline Treatment Stage of Post-Infection & Treatment (Dose mg/kg) & Hepatic Ova Reduction Rate (\%) \\
\hline \multirow[t]{4}{*}{$1-5$ days } & - & - \\
\hline & $\operatorname{HSA}(8)$ & 99.3 \\
\hline & praziquantel (300) & 64.7 \\
\hline & artesunate (300) & 61.3 \\
\hline \multirow[t]{3}{*}{ 7-11 days } & HSA (8) & 98.7 \\
\hline & praziquantel (300) & 68.1 \\
\hline & artesunate (300) & 54.6 \\
\hline \multirow[t]{3}{*}{ 14-19 days } & HSA $(8)$ & 72.6 \\
\hline & praziquantel (300) & 59.5 \\
\hline & artesunate (300) & 97.6 \\
\hline \multirow[t]{3}{*}{ 21-25 days } & HSA $(8)$ & 79.7 \\
\hline & praziquantel (300) & 89.9 \\
\hline & artesunate (300) & 89.6 \\
\hline \multirow[t]{3}{*}{ 28-32 days } & HSA (8) & 75.7 \\
\hline & praziquantel (300) & 98.2 \\
\hline & artesunate (300) & 99.8 \\
\hline \multirow[t]{3}{*}{ 35-39 days } & HSA (8) & 75.4 \\
\hline & praziquantel (300) & 97.8 \\
\hline & artesunate (300) & 99.7 \\
\hline
\end{tabular}


To investigate the tissue responses to the HSA treatment, the liver weight index (liver weight/body weight) and liver disease burden (displayed as mean granuloma diameter) of the untreated mice, infected mice, and HSA-treated mice were analyzed. Intraperitoneal administration of HSA at the single doses $8 \mathrm{mg} \cdot \mathrm{kg}^{-1}$ with 1-day and 7-day, 14-day and 21-day S. japonicum post-infected mice showed a dramatic decrease in the liver index, comparing with the untreated mice (Supplementary Materials Figure S1A). Moreover, HSA achieved lower liver index in mice harboring 1-day-old juvenile S. japonicum than praziquantel or artesunate administration (Figure 3A).

A

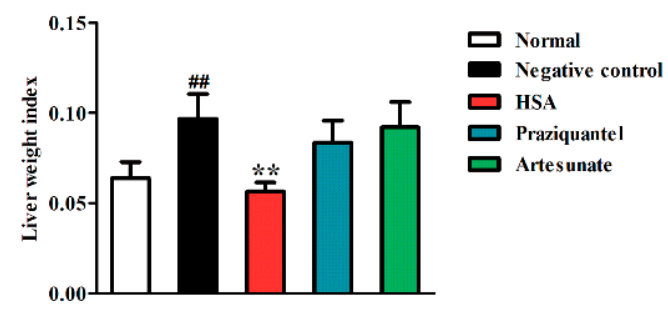

C

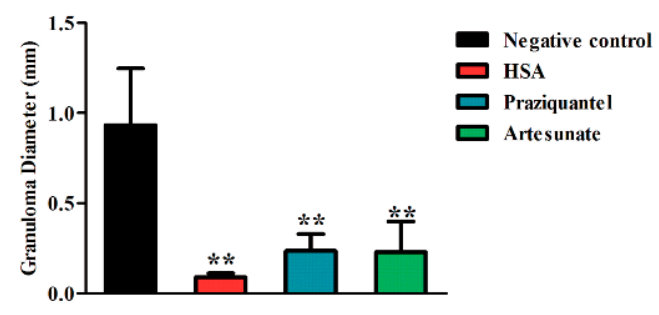

B
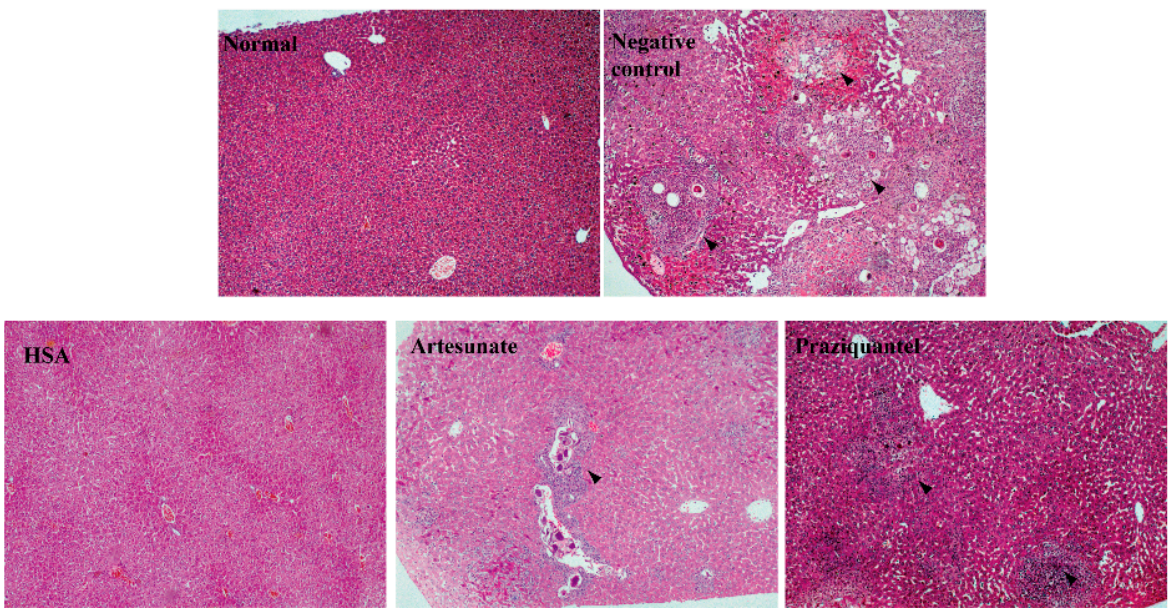

Figure 3. Reduction of hepatic granulomatous inflammation by HSA treated $1-5$ days $S$. japonicum post-infected mice. Mice were treated with administration of $8 \mathrm{mg} \cdot \mathrm{kg}^{-1} \mathrm{HSA}, 300 \mathrm{mg} \cdot \mathrm{kg}^{-1}$ praziquantel (positive control) and $300 \mathrm{mg} \cdot \mathrm{kg}^{-1}$ artesunate (positive control) as antischistosomal treatments for 1-day-old juvenile S. japonicum infection. The effect of HSA on hepatic granulomatous inflammation of infected mice was tested. (A) Liver weight index (liver weight/body weight). Each bar represents the mean $\pm \mathrm{SD}$. ${ }^{\# \#} p<0.01$ vs. Normal, $t$-test; ${ }^{* *} p<0.01$ vs. Negative control, $t$-test; (B) Representative hepatic granulomas of untreated and drug-treated mice. Photographs were taken at $100 \times(\mathrm{H} \& \mathrm{E})$. Black arrows represent the area of granuloma; (C) Quantification of egg-induced liver pathology by measurement of mean granuloma diameter. Each bar represents the mean $\pm \mathrm{SD}$; ** $p<0.01$ vs. Negative control, $t$-test.

Microscopic examination of liver sections stained with hematoxylin and eosin revealed intact liver architecture in all the studied mice groups. The size of granuloma and the intensity of inflammatory infiltrate were evidently variable between the groups in this study (Supplementary Materials Figure S1B). At 7 weeks post-infection, the eggs were surrounded by a dense population of immune cells, such as lymphocytes and eosinophils, followed by a band of fibro-vascular tissue leading to the formation of a mature granuloma in the untreated group (Figure 3B, Black arrows).

Contrarily, examination of the infected livers revealed a significant reduction in the size of granulomatous inflammation in all HSA-treated mice compared with the untreated mice 
(Supplementary Materials Figure S1B). Moreover, by administration of $8 \mathrm{mg} \cdot \mathrm{kg}^{-1} \mathrm{HSA}$ at days $1-5$ post-infection, mature granuloma could hardly be detected and the hepatic lobular architecture restored its normal organization and most hepatocytes showed normal appearance (Figure 3B). The reduction degrees of liver disease burden (displayed as mean granuloma diameter) in S. japonicum-infected mice after HSA treatment are displayed in Supplementary Materials Figure S1C. The significant changes of granuloma diameter were observed from $0.92 \mathrm{~mm}$ in untreated mice to $0.09 \mathrm{~mm}$ in $8 \mathrm{mg} \cdot \mathrm{kg}^{-1} \mathrm{HSA}$ treated 1-5 days post-infected mice (Figure $3 \mathrm{C}$ ). These results suggested that $8 \mathrm{mg} \cdot \mathrm{kg}^{-1} \mathrm{HSA}$ could significantly reduce the granulomatous inflammation.

\subsection{HSA Altered Cytokine Profile in S. japonicum Infected Mice}

In order to investigate the immunomodulatory effect of HSA, we tested the body weight, spleen weight index (spleen weight/body weight) and the expression of Th1/Th2/Th17 cytokines, as the major cytokines responsible for granulomatous inflammatory [26] in HSA treated 1-5 days post-infected mice. For HSA antischistosomal treatment, the body weights of mice in the treatment group were significantly heavier than that of the untreated group, but no significant difference was found between uninfected HSA-treated group and uninfected group (normal control) (Figure 4A). Moreover, the spleen indexes of the mice were also dramatically reduced in the HSA antischistosomal treatment group in comparison to the infected untreated group (Figure 4B).

Schistosome eggs elicit a CD4+ Th cell-mediated hepatic granulomatous inflammation, which is the major pathological consequence of the disease. Granuloma formation is associated with an imbalance in Th1/Th2/Th17 cytokines. In trying to explain the ameliorating effect of HSA on hepatic granuloma size, the serum levels of some cytokines, such as TNF- $\alpha$, IL-4, and IL-17a, which have been involved in Schistosoma granuloma formation in drug-treated mice harboring 1-day-old juvenile S. japonicum were measured. Levels of TNF- $\alpha$ (Figure 4C), IL-4 (Figure 4D) and IL-17a (Figure 4E) were significantly decreased in the HSA-treated group, compared with the untreated group. The levels of TNF- $\alpha$ and IL-17a in HSA treated group was lower than praziquantel and artesunate-treated group. These results revealed that immune responses in 1-day-old juvenile S. japonicum infected mice were reduced by HSA treatment.
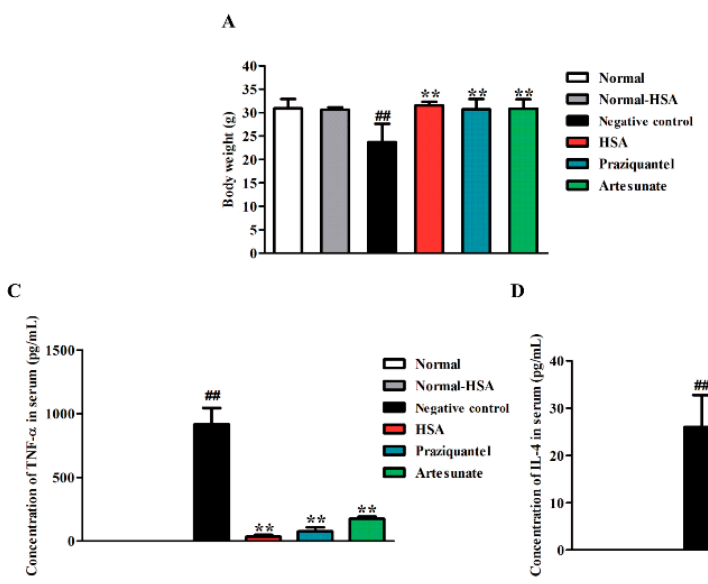

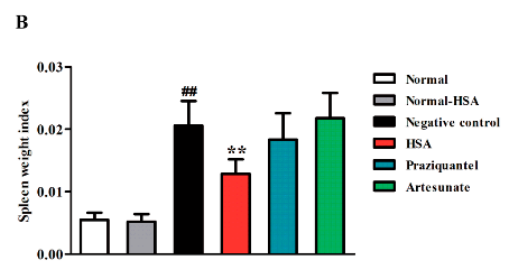

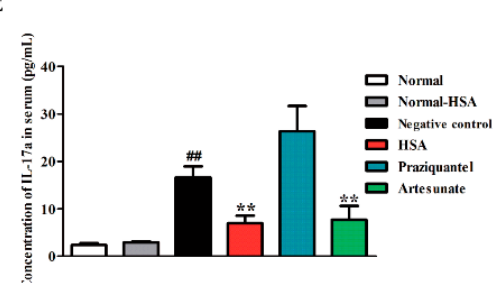

Figure 4. Immune responses in S. japonicum infected mice reduced by HSA. Antischistosomal effects on immune responses of 7-week-infected drug-untreated and drug-treated mice. (A) Statistical analysis of body weights; (B) Spleen weight index (spleen weight/body weight); (C) Expression of TNF- $\alpha$ in S. japonicum infected mice serum with different treatment; (D) Expression of IL-4 in S. japonicum infected mice serum with different treatment; (E) Expression of IL-17a in S. japonicum infected mice serum with different treatment. Each bar represents the mean \pm SD. Each bar represents the mean \pm SD. ${ }^{\# \#} p<0.01$ vs. Normal mice; ${ }^{*} p<0.05$ vs. Negative control; ${ }^{* *} p<0.01$ vs. Negative control, $t$-test. 


\subsection{HSA Protects the Liver with Anti-Fibrotic Effects}

In order to examine the anti-fibrotic effect of HSA on 1-day-old S. japonicum infected mice, the expression of collagen I, TGF- $\beta 1$, TIMP-1 in liver tissue was quantified by immunohistochemistry. Wispy traces of collagen I, TGF- $\beta 1$, TIMP-1 positive staining were sparsely distributed in sections of normal group. At week 7 post-infection, in the untreated group, densely collagen I-, TGF- $\beta 1$ - and TIMP-1-stained cells which could be distinguished by their yellow, brownish-yellow or snuff color surrounded by and infiltrated into the granulomas, and accumulated in fibrotic lesions or stretched along the fibrous septum. In HSA-treated group, the intensity of positive traces was dramatically reduced compared to untreated group; the hepatic lobular architecture was restored to its normal organization and most hepatocytes showed as normal appearance, similar to the one in normal group (Figure 5). These results revealed that HSA inhibited expressions of fibrotic protein expression in liver.

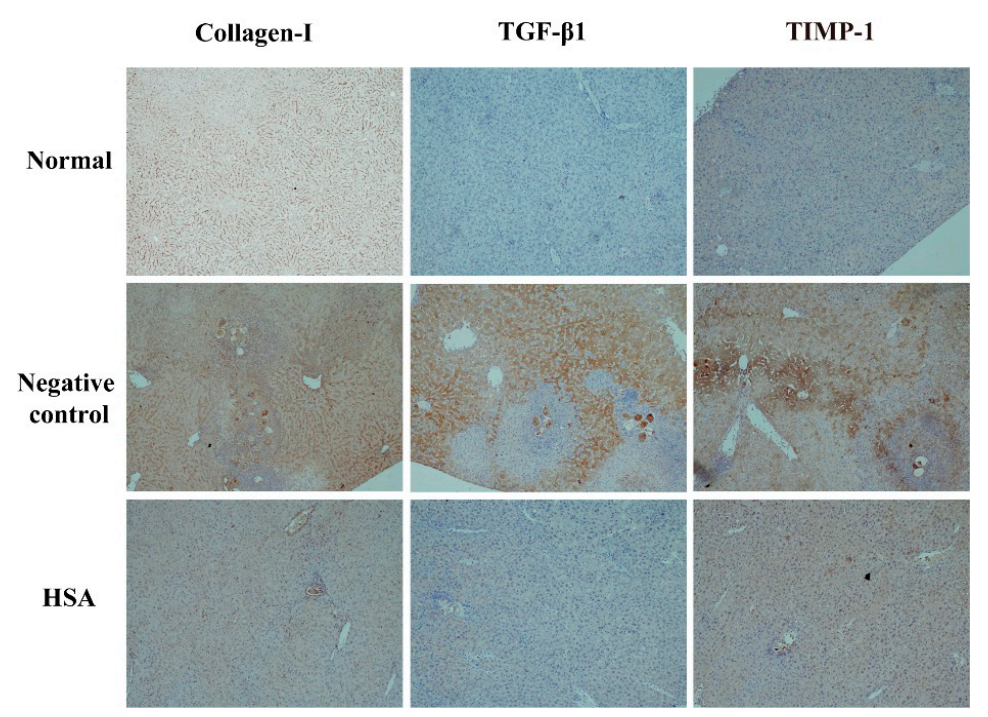

Figure 5. HSA inhibited expressions of fibrotic protein expression in liver of mice. Representative images of immunostaining for TGF- $\beta 1$, TIMP-1, and Collagen I in 7-week-infected drug-untreated (Negative control) and drug-treated mice (HSA) or uninfected mice (Normal). Target protein positive staining is yellow, brownish-yellow or snuff. Original magnification $100 \times$. The histogram shows integral optical densities of target proteins. TGF- $\beta 1$ : Transforming growth factor-beta 1 ; TIMP- 1 : tissue inhibitor of metalloproteinase 1; Collagen I: collagen type I.

\subsection{The Inhibition of S. japonicum NTS by HSA Is Partially Due to the Tegumental Disruption}

Based on in vivo results, HSA exhibits the highly anti-parasite activity on 1-day-old juvenile S. japonicum. Next, we wished to detect the effect of HSA on NTS of S. japonicum in vitro. Figure 6A showed that the positive control praziquantel at a concentration of $96.03 \mu \mathrm{M}\left(30 \mu \mathrm{g} \cdot \mathrm{mL}^{-1}\right) \mathrm{killed}$ $70.98 \%$ parasites within $48 \mathrm{~h}$; artesunate at a concentration of $78.04 \mu \mathrm{M}\left(30 \mu \mathrm{g} \cdot \mathrm{mL}^{-1}\right)$ killed $94.59 \%$ parasites within $48 \mathrm{~h}$ whereas the survival rate of worms belonging to the negative (maintenance medium) control groups was $80.98 \%$. HSA at a concentration of $8.93 \mu \mathrm{M}\left(8 \mu \mathrm{g} \cdot \mathrm{mL}^{-1}\right)$ killed $100 \%$ of parasites after $48 \mathrm{~h}$ of incubation. Scanning electron microscopical examination revealed that the dorsal surface of $S$. japonicum NTS worms cultured in negative control medium (maintenance medium) was provided with numerous large tubercles bearing spines after $4 \mathrm{~h}$, while the positive control $(96.03 \mu \mathrm{M}$ praziquantel or $78.04 \mu \mathrm{M}$ artesunate) had a moderate tegumental alteration in the worms. Interestingly, worm treated with $8.93 \mu \mathrm{M}$ HSA caused the most serious morphological alterations in the tegument of NTS, especially extensive tegumental disruption such as sloughing and erosion (Figure 6B). These data indicated that the morphological changes in the tegument of the worms induced by HSA might be the antischistosomal mechanism. 


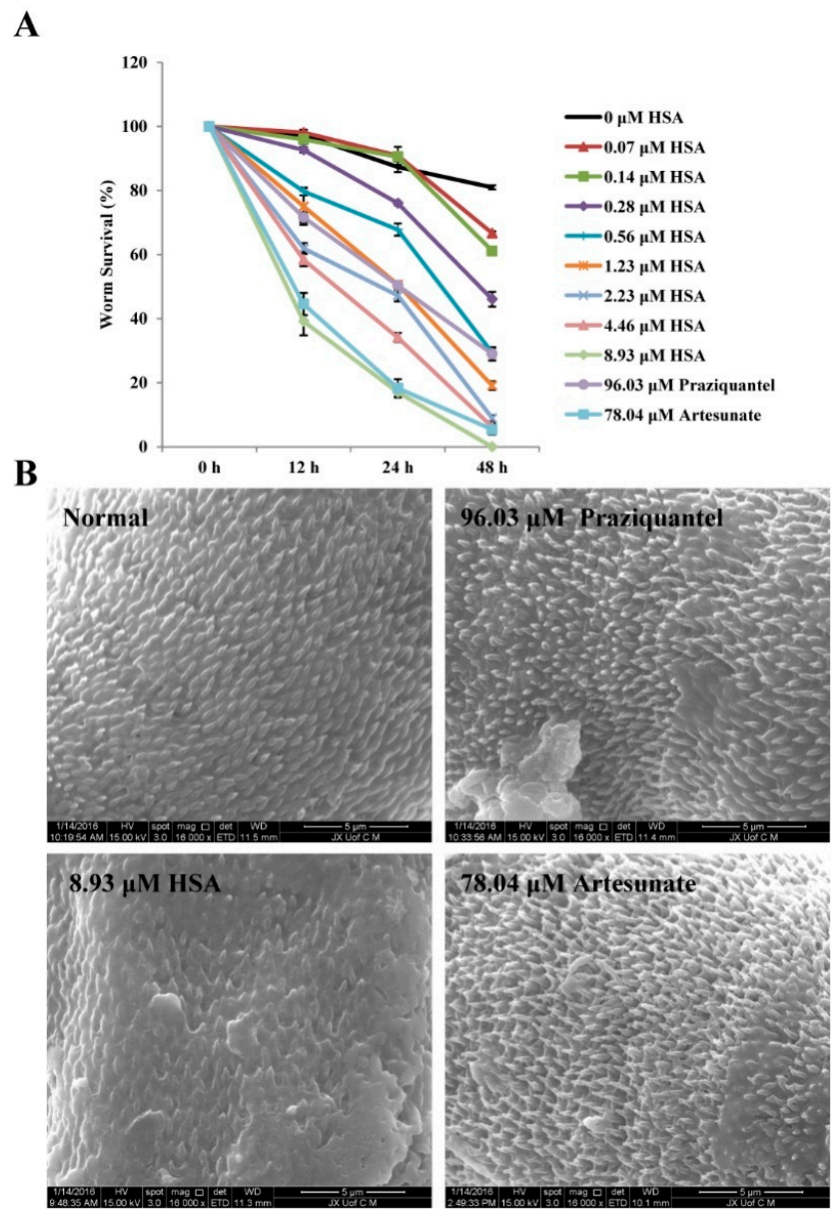

Figure 6. Effects of HSA, praziquantel, and artesunate on NTS S. japonicum in vitro. (A) Effects of 0-8.93 $\mu \mathrm{M}$ HSA, $96.03 \mu \mathrm{M}$ praziquantel and $78.04 \mu \mathrm{M}$ artesunate on NTS S. japonicum in vitro. Each point represents the mean \pm SD. (B) Scanning electron micrograph showing tegument of non-treated NTS S. japonicum, $8.93 \mu \mathrm{M}$ HSA-treated NTS S. japonicum, $96.03 \mu \mathrm{M}$ praziquantel-treated NTS S. japonicum and $78.04 \mu \mathrm{M}$ artesunate-treated NTS S. japonicum.

\section{Discussion}

Many plants reported to have anthelmintic properties actually contain compounds which are secondary metabolites, such as saponins, alkaloids, non-protein amino acids, tannins and other polyphenols, lignin, glycolides that are directly active against parasites [27-30]. The gifts from traditional Chinese medicine, artemisinin and its derivatives, were selected for schistosomiasis control [18]. In this study, we discovered the new antischistosomal activity of HSA, a natural product extracted from the Pulsatilla chinensis (Bunge) Regel. The data showed that HSA was highly active against less than 11 days old juvenile $S$. japonicum harbored in mice (total and female worm burden reductions ranged between $89.5 \%$ and $97.2 \%$. HSA also achieved worm burden reductions from 88.6 to $80.7 \%$ in mice harboring less than 11 days old juvenile S. mansoni, respectively. It is reported that the relative resistance of the larval stages of $S$. mansoni to schistosomicidal drugs might be a result in a therapeutic failure because of the presence of migrating, drug-resistant, immature forms of the parasite [31]. In this regard, HSA may be a potential drug of choice for the prevention and treatment of $S$. japonicum and S. mansoni infections.

The reduction in the female worm recovery and egg load in treated mice was considered as a strong evidence of the efficiency of antischistosomal drugs. Indeed, the significant improvement parameters after treatment of mice at days 1-5 post-infection of S. japonicum with $8 \mathrm{mg} \cdot \mathrm{kg}^{-1} \mathrm{HSA}$ resulted in the significant reduction in female worm burdens (94.7\%) accompanied with a significant decrease in the 
percentage of ova load (99.3\%) compared with the control group. Moreover, the increase in the relative liver weight may be attributed to both egg deposition by worms and several metabolites released by $S$. mansoni, which affect the host hepatic tissue [32]. In this study, intraperitoneal administration of HSA at the single doses $8 \mathrm{mg} \cdot \mathrm{kg}^{-1}$ to 1-day, 7-day, 14-day and 21-day S. japonicum post-infected mice showed a dramatic decrease in the liver index, comparing with the untreated mice. Moreover, HSA achieved lower liver index in mice harboring 1-day-old juvenile S. japonicum than praziquantel or artesunate administration.

Chronic morbidity during infection with S. japonicum and $S$. mansoni develops as a result of schistosome eggs that lodge in the liver, gut and other organs, which causes extensive tissue damage, such as granulomatous inflammation and tissue fibrosis [8]. Therefore, reducing egg counts in the tissues can significantly relieve the symptoms of schistosomiasis $[33,34]$. On histopathological examination of the liver of HSA-treated mice, there were either active small granulomas or healed granulomas. By administration of $8 \mathrm{mg} \cdot \mathrm{kg}^{-1} \mathrm{HSA}$ on 1-5 days post infected mice, mature granuloma could hardly be detected and the hepatic lobular architecture restored its normal organization and most hepatocytes showed normal appearance. The reduction degree of liver disease burden (displayed as mean granuloma diameter) in S. japonicum-infected mice after HSA treatment was consistent with the above results. $8 \mathrm{mg} \cdot \mathrm{kg}^{-1}$ HSA treated $1-5$ days post-infected mice could dramatically reduce the granuloma diameter, from $0.92 \mathrm{~mm}$ in control group to $0.09 \mathrm{~mm}$ in the HSA-treated group. These results suggested that HSA has a considerable effect on Schistosoma pathological changes in the liver. This could be attributed partly to the reduction in the number of eggs trapped in the hepatic tissues and the modulation of serum levels of some cytokines, which are incriminated in the development of Schistosoma granuloma.

Indeed, granuloma formation is dependent on $\mathrm{CD}^{+}$Th cell response. Schistosoma antigens manifest a striking shift from a moderate Th1 to a robust Th2-dominated response with the onset of egg lying around 5-6 weeks [26,35,36]. In order to confirm the ameliorating effect of HSA on hepatic granuloma size, the serum levels of Th1/Th2/Th17 cytokines, which have been involved in Schistosoma granuloma formation, were measured. We found that the levels of TNF- $\alpha$, IL-4, and IL-17a were significantly decreased in HSA 1-day-treated group, compared with the untreated group. Importantly, the levels of TNF- $\alpha$ and IL-17a in HSA treated groups were lower than praziquantel and artesunate-treated group. These results demonstrated HSA treatment promoted a significant and high decrease in granuloma formation as well as in the immune response that underlies granuloma development.

Previous investigate showed that prolonged Th2 [37] and Th17 [38] responses contributed to the development of hepatic granulomatous inflammation and hepatic fibrosis. The mechanism of resulting liver fibrosis is the same that is the activation of Hepatic stellate cells (HSCs) and subsequent extracellular matrix deposition. HSCs, one of the main sources of collagen in the liver, play a crucial role in schistosome-induced fibrogenesis [39]. Chemokines associated with HSCs recruitment and activity, these activated HSCs localized to the granulomas, thus serve as an indicator of collagen deposition in hepatic schistosomiasis [40]. Deposition of collagen, imbalance of matrix metalloproteinase/tissue inhibitor of metalloproteinase (TIMP) and secretion of profibrotic cytokines caused by activated HSCs were described previously in schistosomiasis [41,42]. In additional, TGF- $\beta 1$ promotes collagen synthesis in activated HSCs via pSmad2/3 pathways [43]. To investigate the anti-fibrosis activity of HSA, we detected the expressions of the fibrosis-related marker, collagen I, TGF- $\beta 1$ and TIMP- 1 in infected mice. There was no fibrosis-related marker in the HSA-treated group. Therefore, these results demonstrated that hepatic fibrosis was hardly detected in S. japonicum-infected mice after HSA anti-parasite therapy. In our experiments, the anti-fibrosis effect of HSA might be partly due to its anti-parasite activity, and the anti-inflammation property of HSA would study further.

Based on in vivo results, HSA exhibits the significant anti-parasite effect on 1-day-old S. japonicum, we wonder to detect the effect of HSA on NTS of S. japonicum in vitro. In the present study, HSA at a concentration of $8.93 \mu \mathrm{M}$ killed $100 \%$ of NTS S. japonicum worms after 48 h of incubation; 
however, the $100 \%$ lethal concentration for positive control, praziquantel, and artesunate, in the same culture time was higher. The tegument of schistosomes is an important target for antischistosomal drugs [44]. Various antischistosomal drugs such as praziquantel [45], artemether and artesunate [46,47], mefloquine [48], miltefosine [49], epiisopiloturine [50] and piplartine [51] have been documented for alterations in the tegument of schistosoma species. In the absence of the drug, NTS of S. japonicum showed normal viability without any tegumental changes for $4 \mathrm{~h}$. In the presence of HSA at concentrations of $8.93 \mu \mathrm{M}$, extensive tegumental disruption such as sloughing and erosion was observed by SEM examination, while the positive control (96.03 $\mu \mathrm{M}$ praziquantel or $78.04 \mu \mathrm{M}$ artesunate) had a moderate tegumental alteration in the worms. These in vitro results were consistent with the antischistosomal activity of HSA on 1-day-old juveniles chistosomes harbored in mice.

In all, our data demonstrated for the first time that HSA, the natural product isolated from the Pulsatilla chinensis (Bunge) Regel, exhibits antischistosomal properties in vivo against S. japonicum and S. mansoni. The antischistosomal activity is higher than positive drugs, praziquantel, and artesunate against 1-day-old juvenileschistosomes. In addition, $8 \mathrm{mg} \cdot \mathrm{kg}^{-1} \mathrm{HSA}$ ameliorate the pathological parameters, such as granuloma formation, granulomatous inflammation and liver fibrosis in the S. japonicum infected mice. Furthermore, the antischistosomal activity of HSA on NTS confirmed the in vivo results. Further in vitro and in vivo studies would be launched to elucidate the possible mechanism of action and to study the effect of HSA on schistosomes and other trematodes. These results suggest that HSA may have the possibility to be a useful antischistosomal agent for therapy in human schistosomiasis and provide a basis for future clinical trials.

\section{Materials and Methods}

\subsection{Animals}

ICR mice of similar age and weight (20-25 g) were used for this study. They were purchased from the Experimental Animal Center of Soochow University (Suzhou, China) and were housed under specific pathogen-free conditions. The animal room was controlled under temperature $\left(22 \pm 2{ }^{\circ} \mathrm{C}\right)$, light (12 h light/dark cycle) and humidity (50 $\pm 10 \%)$. All laboratory feed pellets and bedding was autoclaved. The mice were anesthetized using diethyl ether and blood samples were withdrawn from the tail vein of mice. The animal study proposal was approved by the Institutional Animal Care and Use Committee of the Soochow University. Experimental procedures involving animals were performed in accordance with the Regulations for the Administration of Affairs Concerning Experimental Animals approved by the State Council of People's Republic of China.

\subsection{Compounds}

HSA (2.5 g) was prepared in our lab, and the structure (Figure 1) was identified by comparison its spectroscopic data with those of HSA, which are in agreement with those of Pulsatilla saponin B7 [52]. The purity of HSA was determined as $95.2 \%$ by analytical HPLC with PDA detection.

\subsection{In Vivo Studies with S. japonicum}

Mouse (eight per group) was infected percutaneously with $\sim 65$ S. japonicum cercariae. To investigate the dose-response relationship of HSA against both the juvenile and adult $S$. japonicum, 4-8 mg/kg intraperitoneal doses were given to mice 14 days (pre-patent infection) and 35 days (patent infection) post-infection for five consecutive days. To assess the efficacy of HSA against different stages of $S$. japonicum, mice were intraperitoneally treated with a single dose of $8 \mathrm{mg} \cdot \mathrm{kg}^{-1} \mathrm{HSA}_{\text {daily }}$ for 5 consecutive days. Different treatment groups started at either of day 1, 7, 14, 21, 28 and 35 post-infection. In each experiment, infected but untreated mice served as controls. For comparison, praziquantel (300 $\mathrm{mg} \cdot \mathrm{kg}^{-1}$ ) (Sigma-Aldrich Chemie $\mathrm{GmbH}$, St. Louis, MO, USA) or artesunate $\left(300 \mathrm{mg} \cdot \mathrm{kg}^{-1}\right)$ (batch no. 20081213; 99.9\% purity) were orally administered with infected mice as the 
positive control group. At 49 days post-infection, mice were killed and the worms were recovered from the hepatic and port mesenteric veins by the perfusion technique [53].

\subsection{In Vivo Studies with S. mansoni}

Mouse (eight per group) was infected subcutaneously with $\sim 80 \mathrm{~S}$. mansoni cercariae. To study the stage-specific susceptibility of S. mansoni, mice were treated intraperitoneal with a single $8 \mathrm{mg} \cdot \mathrm{kg}^{-1}$ dose of HSA for 5 consecutive days. Each group started treatment at either of day 1, 7, 21, 42 and 49 post-infection. For each experiment, infected but untreated mice served as negative control. Praziquantel $\left(300 \mathrm{mg} \cdot \mathrm{kg}^{-1}\right)$ or artesunate $\left(300 \mathrm{mg} \cdot \mathrm{kg}^{-1}\right)$ were orally administered with infected mice as the positive control. At 56 days post-infection, worms were recovered from the hepatic perfusion as described elsewhere [54,55].

The percentage of reduction in worm numbers after treatment was calculated according to Tendler et al. [56] as follows: $\mathrm{P}=(\mathrm{C}-\mathrm{V} / \mathrm{C}) \times 100$, where $\mathrm{P}=$ percentage of worm burden, $\mathrm{C}=$ mean number of parasites recovered from infected but not treated animals, and $\mathrm{V}=$ mean number of parasites recovered from the treated animals.

The animals were then sacrificed and their livers were separated. Egg count in the liver was demonstrated by taking a weighted portion of the liver and each placed in a test tube containing $5 \mathrm{~mL}$ of $5 \% \mathrm{KOH}$ solution [57]. Eggs were counted after being spread on slides and the number of eggs per tissues weight (gram) was calculated. The calculation of egg reduction rate was similar to the worm burden rate.

\subsection{Histology Analysis}

All mice were weighed and sacrificed. Liver samples were weighted, fixed in $4 \%$ formalin, paraffin embedded and sectioned ( $4 \mathrm{~mm}$ thick). All sections were stained with hematoxylin and eosin to evaluate structural alterations of the hepatic parenchymal cells and to clarify the presence of schistosome eggs and granuloma.

Liver disease burden (displayed as mean granuloma diameter) was measured for individual mice, and the results were reported as the mean with standard deviation of the group. To measure these, six random photographs (CX31, $\times 40$ magnification, Olympus, Tokyo, Japan) were taken from each of three randomly cut liver sections per mouse, the mean diameter $(\mathrm{mm})$ was measured by image analysis software (Image J, NIH, Bethesda, MD, USA). Counts for each photograph were averaged over photographs within animals. The means and standard deviations were calculated for each group.

\subsection{Immunological Analysis}

Mice were anesthetized using diethyl ether after measured the weight of each mouse and then, blood was collected from the sublingual vein. The animals were then sacrificed and their spleens were separated. Blood was obtained from each mouse after sacrifice. Serum was collected from the clotted blood samples after centrifugation at $400 \times g$ for $15 \mathrm{~min}$ at $4{ }^{\circ} \mathrm{C}$, then divided into aliquots and stored at $-80^{\circ} \mathrm{C}$ until use.

Cytokines interleukin (IL)-4, tumor necrosis factor (TNF)- $\alpha$ and IL-17a were measured in the sera of mice by using sandwich ELISAs with anti-cytokine antibodies according to the manufacturer's instructions. BMS613 Mouse IL-4 platinum ELISA, BMS607/3 Mouse TNF- $\alpha$ platinum ELISA, BMS6001 Mouse IL-17a platinum ELISA were purchased from eBiosience (San Diego, CA, USA).

\subsection{Immunohistochemistry Analysis}

Immunohistochemical staining was performed with an HRP-Polymer anti-Mouse/Rabbit IHC Kit (GTX83398, Irvine, CA, USA) The sections were deparaffinized, washed in phosphate-buffered saline (PBS, $0.01 \mathrm{~mol} \cdot \mathrm{L}^{-1}, \mathrm{pH} 7.2$ ) $3 \times 5 \mathrm{~min}$, heated at $100{ }^{\circ} \mathrm{C}$ in a microwave oven $6 \times 2 \mathrm{~min}$, incubated in $3 \% \mathrm{H}_{2} \mathrm{O}_{2}$ in deionized water for $10 \mathrm{~min}$ to block endogenous peroxides activity, and washed $3 \times 5 \mathrm{~min}$ with PBS. The sections were then incubated overnight at $4{ }^{\circ} \mathrm{C}$ with the following primary antibodies: 
anti-transforming growth factor- $\beta 1$ (TGF- $\beta 1$ ) antibody (ab92486, Abcam, Cambridge, MA, USA, 1:500); anti-tissue inhibitor of metalloproteinase-1 (TIMP-1) antibody (ab61224, Abcam, 1:200); anti-collagen I antibody (ab34710, Abcam, 1:500). After washing $3 \times 5$ min with PBS, the appropriate HRP-polymer anti-mouse/rabbit immunoglobulin $\mathrm{G}$ was added to the sections and incubated at $37^{\circ} \mathrm{C}$ for $20 \mathrm{~min}$. The sections were then washed $3 \times 5$ min with PBS, and the color was developed with DAB for 3-5 min. The nuclei were lightly counterstained with hematoxylin.

\subsection{Cultivation of Newly Transformed Schistosomula (NTS-the Larval Stage) S. japonicum and Scanning Electron Microscopy (SEM)}

\subsubsection{Collection of NTS S. japonicum}

NTS were obtained using a transformation method described previously [58]. Briefly, the collected cercarial suspension was cooled, centrifuged and pipetted, and vortexed vigorously in Hanks's balanced salt solution (HBSS) to remove the tails. The NTS suspension was adjusted to a concentration of 100 NTS per $50 \mu \mathrm{L}$ in NTS culture medium, the RPMI 1640 medium (Invitrogen, Carlsbad, CA, USA) (maintenance medium) containing $10 \%$ fetal bovine serum, $100 \mathrm{U} \cdot \mathrm{mL}^{-1}$ penicillin, $100 \mu \mathrm{g} \cdot \mathrm{mL}^{-1}$ streptomycin (Invitrogen). The NTS suspension was then incubated at $37{ }^{\circ} \mathrm{C}, 5 \% \mathrm{CO}_{2}$ in ambient air for $12 \mathrm{~h}$.

\subsubsection{Schistosome Incubation In Vitro with Treatment}

Twelve hours after NTS preparation, approximately 150 S. japonicum NTS per well were cultured in 6 well plate with $4 \mathrm{~mL}$ maintenance medium. The $S$. japonicum were then treated with different concentrations of HSA $(0-8.93 \mu \mathrm{M}), 96.03 \mu \mathrm{M}$ praziquantel or $78.04 \mu \mathrm{M}$ artesunate for $72 \mathrm{~h}$.

\subsubsection{SEM}

The S. japonicum NTS were selected for SEM according to the morphology of worms. Approximately 10 S. japonicum NTS were cultivated in maintenance medium containing $8.93 \mu \mathrm{M}$ HSA, $96.03 \mu \mathrm{M}$ praziquantel or $78.04 \mu \mathrm{M}$ artesunate for $4 \mathrm{~h}$ and then sequentially fixed in $10 \%$ formaldehyde buffer at $4{ }^{\circ} \mathrm{C}$ for $4 \mathrm{~h}$, osmium tetroxide phosphate buffer solution ( $1 \%$ ) at $4{ }^{\circ} \mathrm{C}$ for $2 \mathrm{~h}$. After washing with phosphate buffer solution, the schistosomes were dehydrated in ascending grades of alcohol and critical-point dried in liquid carbon dioxide. Finally, the samples were sputter-coated with gold and examined by SEM (Quanta 250, FEI, Hillsboro, OR, USA).

\subsection{Statistical Analysis}

Means of multiple groups were compared using one-way ANOVA followed by Tukey's multiple comparisons test employing Prims software (GraphPad Software, La Jolla, CA, USA). Data were expressed as mean \pm standard deviation (SD). The data were considered significant if $p<0.05$.

Supplementary Materials: The following are available online.

Author Contributions: L.Y., X.Q., K.N., S.W., and Y.S. designed the experiment. K.N. performed the experiments, analyzed the data and wrote the manuscript. G.H., Y.D., F.Y., Z.W., L.Y. and X.Q. helped with data analysis and revised the manuscript. K.N. and S.W. equally contributed to this work. All the authors agreed that the final approval of the version to be published and ensured questions relating to the accuracy or integrity of any part of the work were appropriately investigated and resolved.

Funding: This paper was funded by National Sciences Foundation of China (No. 81273402), Jiangxi advantage technology innovation team project (No. 2010DQB01700), the Natural science foundation of Jiangxi province (No. 20114BAB215045), and the Natural science foundation of Jiangsu province (No. BK2012620).

Conflicts of Interest: The authors declare no conflicts of interest.

\section{Abbreviations}

HAS, Hederacolchiside A1; HSCs, Hepatic stellate cells; NTS, newly transformed schistosomula; Th cell, T-helper cell; TIMP-1, tissue inhibitor of metalloproteinase-1. 


\section{References}

1. King, C.H. Lifting the burden of schistosomiasis-Defining elements of infection-associated disease and the benefits of antiparasite treatment. J. Infect. Dis. 2007, 196, 653-655. [CrossRef] [PubMed]

2. King, C.H.; Dangerfield-Cha, M. The unacknowledged impact of chronic schistosomiasis. Chronic Illn. 2008, 4, 65-79. [CrossRef] [PubMed]

3. Gray, D.J.; McManus, D.P.; Li, Y.; Williams, G.M.; Bergquist, R.; Ross, A.G. Schistosomiasis elimination: Lessons from the past guide the future. Lancet Infect. Dis. 2010, 10, 733-736. [CrossRef]

4. King, C.H.; Dickman, K.; Tisch, D.J. Reassessment of the cost of chronic helmintic infection: A meta-analysis of disability-related outcomes in endemic schistosomiasis. Lancet 2005, 365, 1561-1569. [CrossRef]

5. Bergquist, R.; Utzinger, J.; McManus, D.P. Trick or treat: The role of vaccines in integrated schistosomiasis control. PLoS Negl. Trop. Dis. 2008, 2, e244. [CrossRef] [PubMed]

6. Hotez, P.J.; Molyneux, D.H.; Fenwick, A.; Ottesen, E.; Ehrlich Sachs, S.; Sachs, J.D. Incorporating a rapid-impact package for neglected tropical diseases with programs for HIV/AIDS, tuberculosis, and malaria. PLoS Med. 2006, 3, e102. [CrossRef] [PubMed]

7. Steinmann, P.; Keiser, J.; Bos, R.; Tanner, M.; Utzinger, J. Schistosomiasis and water resources development: Systematic review, meta-analysis, and estimates of people at risk. Lancet Infect. Dis. 2006, 6, 411-425. [CrossRef]

8. Gryseels, B.; Polman, K.; Clerinx, J.; Kestens, L. Human schistosomiasis. Lancet 2006, 368, $1106-1118$. [CrossRef]

9. Cioli, D.; Pica-Mattoccia, L.; Basso, A.; Guidi, A. Schistosomiasis control: Praziquantel forever? Mol. Biochem. Parasitol. 2014, 195, 23-29. [CrossRef] [PubMed]

10. Fallon, P.G.; Doenhoff, M.J. Drug-resistant schistosomiasis: Resistance to praziquantel and oxamniquine induced in Schistosoma mansoni in mice is drug specific. Am. J. Trop. Med. Hyg. 1994, 51, 83-88. [CrossRef] [PubMed]

11. Ismail, M.; Metwally, A.; Farghaly, A.; Bruce, J.; Tao, L.F.; Bennett, J.L. Characterization of isolates of Schistosoma mansoni from egyptian villagers that tolerate high doses of praziquantel. Am. J. Trop. Med. Hyg. 1996, 55, 214-218. [CrossRef] [PubMed]

12. Abdul-Ghani, R.A.; Loutfy, N.; Hassan, A. Experimentally promising antischistosomal drugs: A review of some drug candidates not reaching the clinical use. Parasitol. Res. 2009, 105, 899-906. [CrossRef] [PubMed]

13. Colley, D.G. Morbidity control of Schistosomiasis by mass drug administration: How can we do it best and what will it take to move on to elimination? Trop. Med. Health 2014, 42, 25-32. [CrossRef] [PubMed]

14. Kayser, O.; Kiderlen, A.F.; Croft, S.L. Natural products as antiparasitic drugs. Parasitol. Res. 2003, 90 (Suppl. 2), S55-S62. [CrossRef] [PubMed]

15. Tagboto, S.; Townson, S. Antiparasitic properties of medicinal plants and other naturally occurring products. Adv. Parasitol. 2001, 50, 199-295. [PubMed]

16. Chan-Bacab, M.J.; Pena-Rodriguez, L.M. Plant natural products with leishmanicidal activity. Nat. Prod. Rep. 2001, 18, 674-688. [PubMed]

17. Newman, D.J.; Cragg, G.M. Natural products as sources of new drugs over the 30 years from 1981 to 2010. J. Nat. Prod. 2012, 75, 311-335. [CrossRef] [PubMed]

18. Utzinger, J.; Xiao, S.H.; Tanner, M.; Keiser, J. Artemisinins for schistosomiasis and beyond. Curr. Opin. Investig. Drugs 2007, 8, 105-116. [PubMed]

19. Mimaki, Y.; Kuroda, M.; Asano, T.; Sashida, Y. Triterpene saponins and lignans from the roots of Pulsatilla chinensis and their cytotoxic activity against hl-60 cells. J. Nat. Prod. 1999, 62, 1279-1283. [CrossRef] [PubMed]

20. Liu, T.; Ye, L.; Guan, X.; Liang, X.; Li, C.; Sun, Q.; Liu, Y.; Chen, S.; Bang, F.; Liu, B. Immunopontentiating and antitumor activities of a polysaccharide from Pulsatilla chinensis (bunge) regel. Int. J. Biol. Macromol. 2013, 54, 225-229. [CrossRef] [PubMed]

21. Cheng, L.; Zhang, M.; Zhang, P.; Song, Z.; Ma, Z.; Qu, H. Silver complexation and tandem mass spectrometry for differentiation of triterpenoid saponins from the roots of Pulsatilla chinensis (bunge) regel. Rapid Commun. Mass Spectrom. 2008, 22, 3783-3790. [CrossRef] [PubMed]

22. Xu, Q.M.; Shu, Z.; He, W.J.; Chen, L.Y.; Yang, S.L.; Yang, G.; Liu, Y.L.; Li, X.R. Antitumor activity of Pulsatilla chinensis (bunge) regel saponins in human liver tumor 7402 cells in vitro and in vivo. Phytomedicine 2012, 19, 293-300. [CrossRef] [PubMed] 
23. Li, L.D.; Li, W.C.; Liu, C.W.; Shi, W.J.; Gong, P.T.; Li, J.H.; Zhang, G.C.; Yang, J.; Li, H.; Zhang, X.C. Giardia intestinalis: Effects of Pulsatilla chinensis extracts on trophozoites. Parasitol. Res. 2012, 111, 1929-1935. [CrossRef] [PubMed]

24. Lee, H.S.; Beon, M.S.; Kim, M.K. Selective growth inhibitor toward human intestinal bacteria derived from Pulsatilla cernua root. J. Agric. Food Chem. 2001, 49, 4656-4661. [CrossRef] [PubMed]

25. Fang, Y.; Wang, R.; He, M.; Huang, H.; Wang, Q.; Yang, Z.; Li, Y.; Yang, S.; Jin, Y. Nitric oxide-donating derivatives of hederacolchiside A1: Synthesis and biological evaluation in vitro and in vivo as potential anticancer agents. Bioorg. Med. Chem. Lett. 2017, 27, 98-101. [CrossRef] [PubMed]

26. Wilson, M.S.; Mentink-Kane, M.M.; Pesce, J.T.; Ramalingam, T.R.; Thompson, R.; Wynn, T.A. Immunopathology of schistosomiasis. Immunol. Cell Biol. 2007, 85, 148-154. [CrossRef] [PubMed]

27. Mantawy, M.M.; Ali, H.F.; Rizk, M.Z. Therapeutic effects of allium sativum and allium cepa in Schistosoma mansoni experimental infection. Rev. Inst. Med. Trop. Sao Paulo 2011, 53, 155-163. [CrossRef] [PubMed]

28. Mantawy, M.M.; Aly, H.F.; Zayed, N.; Fahmy, Z.H. Antioxidant and schistosomicidal effect of allium sativum and allium cepa against Schistosoma mansoni different stages. Eur. Rev. Med. Pharmacol. Sci. 2012, 16 (Suppl. 3), 69-80. [PubMed]

29. Seifel-Din, S.H.; El-Lakkany, N.M.; Mohamed, M.A.; Hamed, M.M.; Sterner, O.; Botros, S.S. Potential effect of the medicinal plants Calotropis procera, Ficus elastica and Zingiber officinale against Schistosoma mansoni in mice. Pharm. Biol. 2014, 52, 144-150. [CrossRef] [PubMed]

30. Mostafa, O.M.; Eid, R.A.; Adly, M.A. Antischistosomal activity of ginger (Zingiber officinale) against Schistosoma mansoni harbored in c57 mice. Parasitol. Res. 2011, 109, 395-403. [CrossRef] [PubMed]

31. Silva, L.M.; Menezes, R.M.; de Oliveira, S.A.; Andrade, Z.A. Chemotherapeutic effects on larval stages of Schistosoma mansoni during infection and re-infection of mice. Rev. Soc. Bras. Med. Trop. 2003, 36, 335-341. [CrossRef] [PubMed]

32. Awney, H.A.; Ghzlan, H.E.; Sheweita, S.A.; Mostafa, M.H. Different levels of Schistosoma mansoni infection increased the mutagenicity of benzo(a)pyrene, the activity of aryl hydrocarbon hydroxylase and the formation of hepatic microsomal hydrogen peroxide. Toxicology 2001, 163, 213-218. [CrossRef]

33. Bergquist, N.R. Schistosomiasis: From risk assessment to control. Trends Parasitol. 2002, 18, 309-314. [CrossRef]

34. Burke, M.L.; Jones, M.K.; Gobert, G.N.; Li, Y.S.; Ellis, M.K.; McManus, D.P. Immunopathogenesis of human schistosomiasis. Parasite Immunol. 2009, 31, 163-176. [CrossRef] [PubMed]

35. Wynn, T.A.; Thompson, R.W.; Cheever, A.W.; Mentink-Kane, M.M. Immunopathogenesis of schistosomiasis. Immunol. Rev. 2004, 201, 156-167. [CrossRef] [PubMed]

36. Pearce, E.J.; MacDonald, A.S. The immunobiology of schistosomiasis. Nat. Rev. Immunol. 2002, 2, $499-511$. [CrossRef] [PubMed]

37. Cheever, A.W.; Hoffmann, K.F.; Wynn, T.A. Immunopathology of Schistosomiasis mansoni in mice and men. Immunol. Today 2000, 21, 465-466. [CrossRef]

38. Shainheit, M.G.; Lasocki, K.W.; Finger, E.; Larkin, B.M.; Smith, P.M.; Sharpe, A.H.; Dinarello, C.A.; Rutitzky, L.I.; Stadecker, M.J. The pathogenic th17 cell response to major schistosome egg antigen is sequentially dependent on il-23 and il-1beta. J. Immunol. 2011, 187, 5328-5335. [CrossRef] [PubMed]

39. Friedman, S.L. Mechanisms of hepatic fibrogenesis. Gastroenterology 2008, 134, 1655-1669. [CrossRef] [PubMed]

40. Bartley, P.B.; Ramm, G.A.; Jones, M.K.; Ruddell, R.G.; Li, Y.; McManus, D.P. A contributory role for activated hepatic stellate cells in the dynamics of Schistosoma japonicum egg-induced fibrosis. Int. J. Parasitol. 2006, 36, 993-1001. [CrossRef] [PubMed]

41. Gomez, D.E.; De Lorenzo, M.S.; Alonso, D.F.; Andrade, Z.A. Expression of metalloproteinases (MMP-1, MMP-2, and MMP-9) and their inhibitors (TIMP-1 and TIMP-2) in schistosomal portal fibrosis. Am. J. Trop. Med. Hyg. 1999, 61, 9-13. [CrossRef] [PubMed]

42. Hemmann, S.; Graf, J.; Roderfeld, M.; Roeb, E. Expression of mmps and timps in liver fibrosis-A systematic review with special emphasis on anti-fibrotic strategies. J. Hepatol. 2007, 46, 955-975. [CrossRef] [PubMed]

43. Yoshida, K.; Matsuzaki, K. Differential regulation of TGF-beta/Smad signaling in hepatic stellate cells between acute and chronic liver injuries. Front. Physiol. 2012, 3, 53. [CrossRef] [PubMed]

44. De Moraes, J. Natural products with antischistosomal activity. Future Med. Chem. 2015, 7, 801-820. [CrossRef] [PubMed] 
45. Staudt, U.; Schmahl, G.; Blaschke, G.; Mehlhorn, H. Light and scanning electron microscopy studies on the effects of the enantiomers of praziquantel and its main metabolite on Schistosoma mansoni in vitro. Parasitol. Res. 1992, 78, 392-397. [CrossRef] [PubMed]

46. Jiraungkoorskul, W.; Sahaphong, S.; Sobhon, P.; Riengrojpitak, S.; Kangwanrangsan, N. Effects of praziquantel and artesunate on the tegument of adult Schistosoma mekongi harboured in mice. Parasitol. Int. 2005, 54, 177-183. [CrossRef] [PubMed]

47. Jiraungkoorskul, W.; Sahaphong, S.; Sobhon, P.; Riengrojpitak, S.; Kangwanrangsan, N. Schistosoma mekongi: The in vitro effect of praziquantel and artesunate on the adult fluke. Exp. Parasitol. 2006, 113, 16-23. [CrossRef] [PubMed]

48. Manneck, T.; Haggenmuller, Y.; Keiser, J. Morphological effects and tegumental alterations induced by mefloquine on schistosomula and adult flukes of Schistosoma mansoni. Parasitology 2010, 137, 85-98. [CrossRef] [PubMed]

49. Eissa, M.M.; El-Azzouni, M.Z.; Amer, E.I.; Baddour, N.M. Miltefosine, a promising novel agent for schistosomiasis mansoni. Int. J. Parasitol. 2011, 41, 235-242. [CrossRef] [PubMed]

50. Veras, L.M.; Guimaraes, M.A.; Campelo, Y.D.; Vieira, M.M.; Nascimento, C.; Lima, D.F.; Vasconcelos, L.; Nakano, E.; Kuckelhaus, S.S.; Batista, M.C.; et al. Activity of epiisopiloturine against Schistosoma mansoni. Curr. Med. Chem. 2012, 19, 2051-2058. [CrossRef] [PubMed]

51. De Moraes, J.; Nascimento, C.; Yamaguchi, L.F.; Kato, M.J.; Nakano, E. Schistosoma mansoni: In vitro schistosomicidal activity and tegumental alterations induced by piplartine on schistosomula. Exp. Parasitol. 2012, 132, 222-227. [CrossRef] [PubMed]

52. Ekabo, O.A.; Farnsworth, N.R.; Henderson, T.O.; Mao, G.; Mukherjee, R. Antifungal and molluscicidal saponins from Serjania salzmanniana. J. Nat. Prod. 1996, 59, 431-435. [CrossRef] [PubMed]

53. Yolles, T.K.; Moore, D.V.; DeGiusti, D.L.; Ripsom, C.A.; Meleney, H.E. A technique for the perfusion of laboratory animals for the recovery of schistosomes. J. Parasitol. 1947, 33, 419-426. [CrossRef] [PubMed]

54. Smithers, S.R.; Terry, R.J. The infection of laboratory hosts with cercariae of Schistosoma mansoni and the recovery of the adult worms. Parasitology 1965, 55, 695-700. [CrossRef] [PubMed]

55. Xiao, S.H.; Keiser, J.; Chollet, J.; Utzinger, J.; Dong, Y.; Endriss, Y.; Vennerstrom, J.L.; Tanner, M. In vitro and in vivo activities of synthetic trioxolanes against major human schistosome species. Antimicrob. Agents Chemother. 2007, 51, 1440-1445. [CrossRef] [PubMed]

56. Tendler, M.; Pinto, R.M.; Oliveira Lima, A.; Gebara, G.; Katz, N. Schistosoma mansoni: Vaccination with adult worm antigens. Int. J. Parasitol. 1986, 16, 347-352. [CrossRef]

57. Cheever, A.W.; Anderson, L.A. Rate of destruction of Schistosoma mansoni eggs in the tissues of mice. Am. J. Trop. Med. Hyg. 1971, 20, 62-68. [CrossRef] [PubMed]

58. Keiser, J. In vitro and in vivo trematode models for chemotherapeutic studies. Parasitology 2010, 137, 589-603. [CrossRef] [PubMed]

Sample Availability: Samples of the compounds Hederacolchiside A1 are available from the authors.

(C) 2018 by the authors. Licensee MDPI, Basel, Switzerland. This article is an open access article distributed under the terms and conditions of the Creative Commons Attribution (CC BY) license (http:/ / creativecommons.org/licenses/by/4.0/). 